\title{
Assessment of Potential Unconventional Carboniferous-Permian Gas Resources of the Liaohe Basin Eastern Uplift, Liaoning Province, China, 2011
}

The U.S. Geological Survey estimated a mean of 448 billion cubic feet of potential technically recoverable unconventional natural gas in Carboniferous and Permian coal-bearing strata in the eastern uplift of the Liaohe Basin, Liaoning Province, China.

\section{Introduction}

The U.S. Geological Survey (USGS), in cooperation with the U.S. Department of State, is assessing the potential for unconventional oil and gas resources (shale gas, shale oil, tight gas, and coalbed gas) in priority geologic provinces worldwide. In 2010, the USGS, in cooperation with the Chinese National Energy Agency, PetroChina, and PetroChina's Liaohe Oil Field Company, was requested to evaluate and assess the unconventional resource potential of Carboniferous and Permian coal-bearing strata within the eastern uplift area of the Liaohe

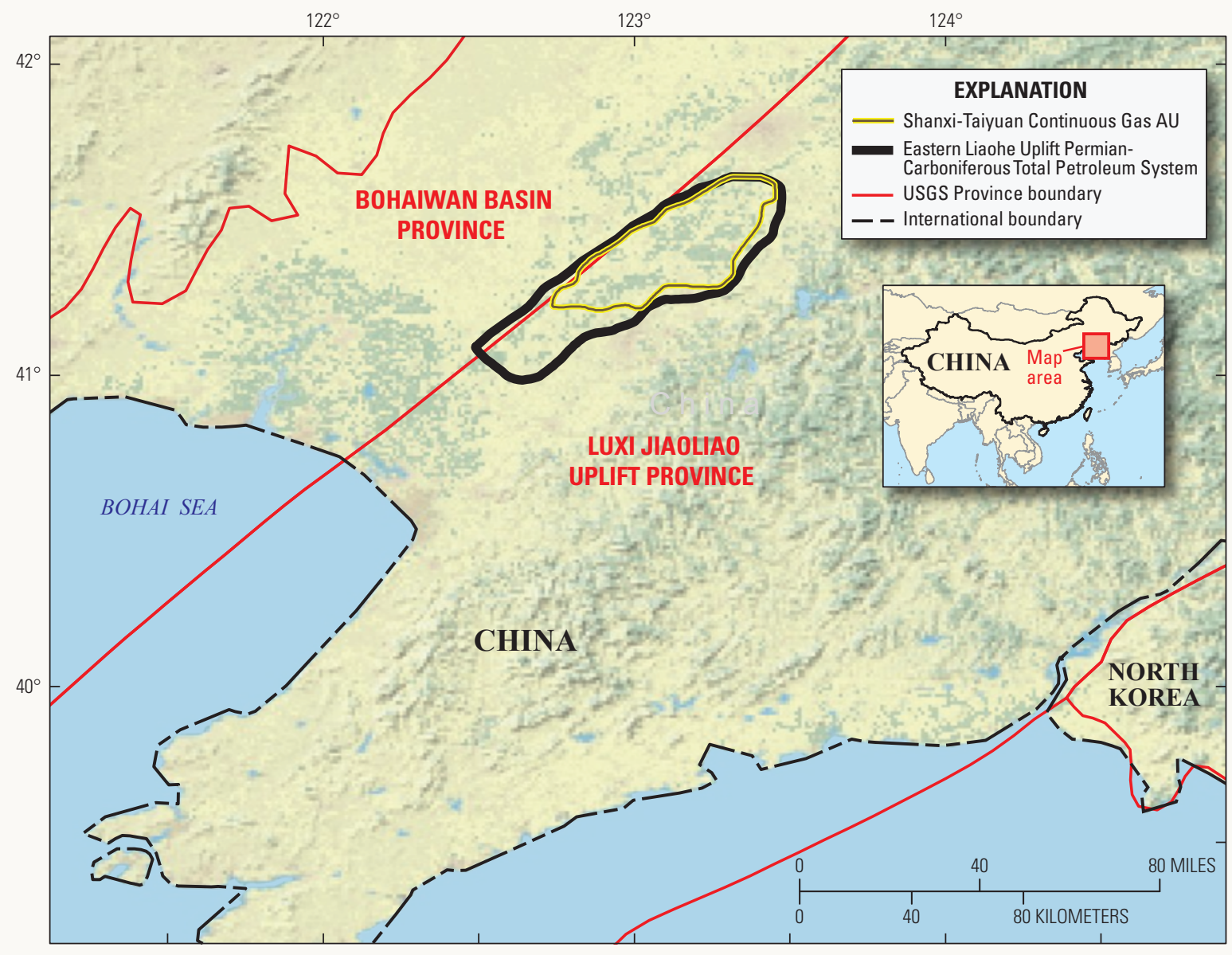

Basin, Liaoning Province of the People's Republic of China (figs. 1, 2). The basin is considered the third most important hydrocarbon-producing basin in China and contains reserves estimated at about 15 billion barrels of oil ( $\mathrm{Gu}$ and others, 2002; Hu and others, 2005). Much of the geological information used in this study was obtained through a proprietary data agreement with PetroChina.

The Liaohe Basin, which is located adjacent to the northeast end of the Bohai Sea, is a wedge-shaped Tertiary rift developed on a paleohigh and can be subdivided into several southwestto-northeast-trending structural units consisting of a series of uplifts and depressions (inset map, fig. 2; Chen and others, 1999). The depressions developed on a basement comprised of Precambrian, Paleozoic, and Mesozoic rocks. Sagging of the eastern depression adjacent to and west of the eastern uplift commenced at about 65 million years ago (Sun, 1999). The eastern uplift is the easternmost structural element of the basin complex and is located within the USGS Luxi Jiaoliao Uplift Province (fig.1). Exploration of oil and gas in the adjacent eastern depression to the west has been ongoing since 1970; the first oil-field discovery occurred in 1975. However, little exploration has occurred in the adjacent eastern uplift to the east (inset map, fig. 2).

Figure 1. Location of U.S. Geological Survey geologic provinces, the boundaries of the Eastern Liaohe Uplift Permian-Carboniferous Total Petroleum System, and Shanxi-Taiyuan Continuous Gas Assessment Unit (AU) assessed in this study. Liaohe Basin corresponds to the onshore part of the Bohaiwan Basin Province. 


\section{Carboniferous-Permian Continuous Gas System in the Eastern Uplift}

The Carboniferous Taiyuan and Permian Shanxi Formations compose a paralic succession of sandstone, siltstone, carbonaceous mudstone, and coal deposited in a range of environments at or near sea level. These include fluvial-alluvial coastal-plain systems, delta-plain and delta-front systems, marginal marine settings (lagoons, bays, and tidal flats), and shoreface-shelf systems with barrier bars and islands. A generalized stratigraphic section, shown in figure 2, contains numerous coals interbedded with sandstone, siltstone, and shale throughout the Carboniferous Taiyuan Formation and within the lower part of the Permian Shanxi Formation. Coal beds in these formations formed in lower coastal plain marshes and mires.
Vitrinite reflectance analyses of samples from wells of the northern area of the uplift indicate that the coals are low-volatile bituminous to semi-anthracite in rank. Geophysical well logs indicate a zone of strong gas shows that correlate to this coalbearing section, with distinct gas kicks adjacent to coal beds; some gas shows are also indicated in associated clastic beds.

Equivalent Carboniferous and Permian formations in China's Ordos Basin (1,200 to 1,400 kilometers to the southwest of Liaohe Basin's eastern uplift) produce gas in giant fields from tight sandstone reservoirs that are sourced from interbedded coal and carbonaceous shale (Yang and others, 2005; Dai and others, 2008). Depositional environments of the Taiyuan and Shanxi Formations in the Ordos Basin include fluvial-deltaic, flood plain, swamp, tidal flat, and restricted platform (Yang and others, 2008).

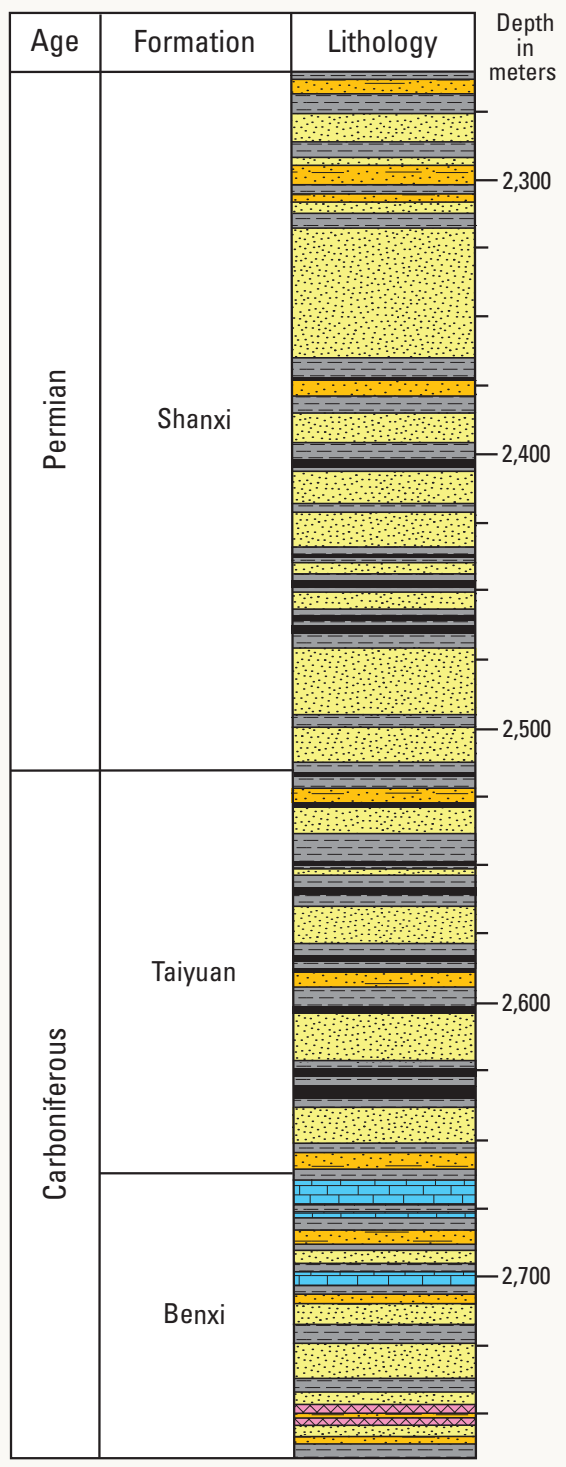

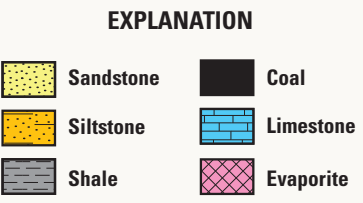

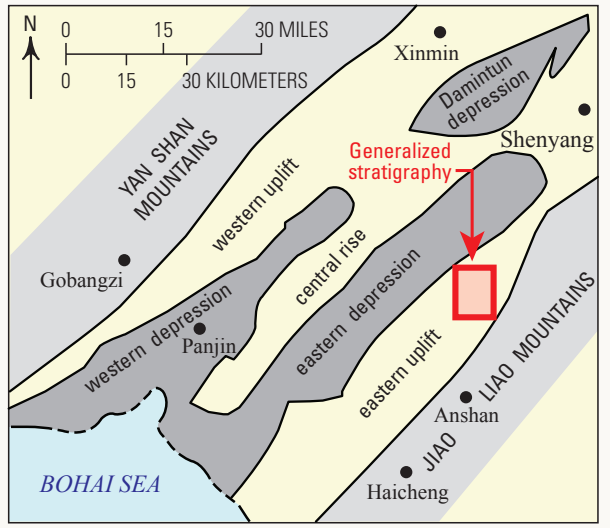

Figure 2. Generalized subsurface stratigraphic section (left) of coalbearing strata of the Carboniferous Taiyuan Formation and Permian Shanxi Formation and the underlying Carboniferous Benxi Formation, in the northern part of the eastern uplift. The inset map illustrates structural subdivisions of depressions and uplifts of the Liaohe Basin (area between the Yan Shan and Jiao Liao Mountains) and location of stratigraphic section. 


\section{Total Petroleum System and Assessment Unit}

For this assessment, one total petroleum system (TPS) (the Eastern Liaohe Uplift Permian-Carboniferous TPS), and one assessment unit (AU) (the Shanxi-Taiyuan Continuous Gas AU), were defined on the basis of geology and then were mapped (fig. 1) using geographic information system methods. The Shanxi-Taiyuan Continuous Gas AU covers an area of about 1,380 square kilometers. A geologic model was formulated for the $\mathrm{AU}$ and geologic analogs of similar unconventional gas resource plays were used to aid in the final assessment.

\section{Methodology and Resource Summary}

Definitions of the TPS and AU and construction of the geologic model were based on proprietary information provided by PetroChina's Liaohe Oil Field Company and published literature. The Shanxi-Taiyuan Continuous Gas AU was assessed for undiscovered, technically recoverable, nonassociated unconventional gas; coproduct ratios were used to calculate the volumes of natural gas liquids.
To assist in the input for the Shanxi-Taiyuan Continuous Gas AU, two proven unconventional gas resource plays were used as analogs: (1) the upper Paleozoic Hartshorne coal, Arkoma Basin, Okla., U.S.A. (Houseknecht and others, 2010); and (2) published geology and production data from the giant tight-gas sandstone Sulige field in the Ordos Basin, China. In the Arkoma Basin, commingled coalbed and tight sandstone gas production is from a coal-bearing, fluvial-deltaic section of Pennsylvanian (late Carboniferous) age. In the Ordos Basin, Sulige field and other adjacent fields produce gas from a Carboniferous-Permian coal-bearing section of tight sandstones that is stratigraphically equivalent to that of the Shanxi-Taiyuan Continuous Gas AU. Analog data from U.S. accumulations included estimated ultimate recoveries (EUR) from gas wells, mean drainage areas of wells (cell sizes), and ranges of well success ratios. Key assessment input data are listed in table 1.

The USGS assessed undiscovered unconventional gas resources in the Shanxi-Taiyuan Continuous Gas AU of the Eastern Liaohe Uplift Permian-Carboniferous TPS at mean totals of 448 billion cubic feet (BCFG), with a range from 179 $\mathrm{BCFG}$ to $848 \mathrm{BCFG}$, and 2 million barrels of natural gas liquids (MMBNGL), with a range from 1 to 5 MMBNGL (table 2).

Table 1. Key assessment input data for continuous gas assessment unit in the Liaohe Basin.

[EUR (estimated ultimate recovery per well), cell size, and success ratios are from U.S. continuous gas analogs. BCFG, billion cubic feet of gas. The average EUR input is the minimum, median, maximum, and calculated mean]

\begin{tabular}{|l|r|r|r|r|}
\hline \multirow{2}{*}{ Assessment input data } & \multicolumn{4}{|c|}{ Shanxi-Taiyuan Continuous Gas AU } \\
\cline { 2 - 5 } & Minimum & \multicolumn{1}{|c|}{ Mode } & Maximum & Calculated mean \\
\hline Potential production area of AU (acres) & 42,000 & 202,000 & 342,000 & 195,333 \\
\hline Average drainage area of wells (acres) & 120 & 160 & 200 & 160 \\
\hline Average EUR (BCFG) & 0.2 & 0.4 & 1.2 & 0.44 \\
\hline Success ratios (\%) & 70 & 85 & 95 & 83.3 \\
\hline
\end{tabular}

Table 2. Assessment results for potential unconventional gas in the Shanxi and Taiyuan Formations, Liaohe Basin Eastern Uplift, China.

[MMBO, million barrels of oil; BCFG, billion cubic feet of gas; NGL, natural gas liquids; MMBNGL, million barrels of natural gas liquids. Results shown are fully risked estimates. For gas accumulations, all liquids are included as NGL. F95 represents a 95 percent chance of at least the amount tabulated; other fractiles are defined similarly. AU probability is the chance of at least one well within the AU having a production capacity of the minimum estimated ultimate recovery. Gray shading indicates not applicable]

\begin{tabular}{|c|c|c|c|c|c|c|c|c|c|c|c|c|c|c|}
\hline \multirow{3}{*}{$\begin{array}{l}\text { Total petroleum systems } \\
\text { (TPS) } \\
\text { and Assessment Units (AU) }\end{array}$} & \multirow{3}{*}{$\underset{\text { probability }}{\text { AU }}$} & \multirow{3}{*}{$\begin{array}{l}\text { Field } \\
\text { type }\end{array}$} & \multicolumn{12}{|c|}{ Total undiscovered resources } \\
\hline & & & \multicolumn{4}{|c|}{ Oil (MMBO) } & \multicolumn{4}{|c|}{ Gas (BCFG) } & \multicolumn{4}{|c|}{ NGL (MMBNGL) } \\
\hline & & & F95 & F50 & $\mathrm{F5}$ & Mean & F95 & F50 & $\mathrm{F5}$ & Mean & F95 & $\mathrm{F50}$ & $\mathrm{F5}$ & Mean \\
\hline $\begin{array}{l}\text { Shanxi-Taiyuan Continuous } \\
\text { Gas AU }\end{array}$ & 1 & Gas & & & & & 179 & 410 & 848 & 448 & 1 & 2 & 5 & 2 \\
\hline
\end{tabular}




\section{References}

Chen, Z.Y., Yan, H., Li, J.S., Zhang, G., Zhang, Z.W., and Liu, B.Z., 1999, Relationship between Tertiary volcanic rocks and hydrocarbons in the Liaohe basin, People's Republic of China: American Association of Petroleum Geologists Bulletin, v. 83, p. 1003-1014.

Dai, J., Zou, C., Qin, S., Tao, S., Ding, W., Liu, Q., and Hu, A., 2008, Geology of giant gas fields of China: Marine and Petroleum Geology, v. 25, p. 320-334.

Gu, L., Ren, Z., Wu, C., Zhao, M., and Qiu, J., 2002, Hydrocarbon reservoirs in a trachyte porphyry intrusion in the Eastern depression of the Liaohe basin, northeast China: American Association of Petroleum Geologists Bulletin, v. 86, p. 1821-1832.

Houseknecht, D.W., Coleman, J.L., Milici, R.C., Garrity, C.P., Rouse, W.A., Fulk, B.R., Paxton, S.T., Abbott, M.M., Mars, J.C., Cook, T.A., Schenk, C.J., Charpentier, R.R., Klett, T.R., Pollastro, R.M., and Ellis, G.S., 2010, Assessment of undiscovered natural gas resources of the Arkoma Basin Province and geologically related areas: U.S. Geological Survey Fact Sheet 2010-3042, 4 p.
Hu, L., Fuhrman, A., Poelchau, H.S., Horsfield, B., Zhang, Z., Wu, T., Chen, Y., and Li, J., 2005, Numerical simulation of petroleum generation and migration in the Qingshui sag, western depression of the Liaohe basin, China: American Association of Petroleum Geologists Bulletin, v. 89, p. 1629-1649.

Sun, H.J., 1999, Petroleum system and exploration prospect evaluation of Eastern depression, Liaohe basin: Nanjing, China, Nanjing University, Ph.D. dissertation, 284 p.

[in Chinese with English abstract]

Yang, Y., Li, W., and Ma, L., 2005, Tectonic and stratigraphic controls on hydrocarbon systems in the Ordos basin-A multicyclic cratonic basin in central China: American Association of Petroleum Geologists Bulletin, v. 89, p. 255-269.

Yang, H., Fu, J., Wei, X., and Liu, X., 2008, Sulige field in the Ordos basin-Geological setting, field discovery and tight gas reservoirs: Marine and Petroleum Geology, v. 25, p. $387-400$.

\section{For Further Information}

Supporting studies of the geologic models and the methodology used in the assessment of the eastern uplift, Liaohe Basin, China, are in progress. Assessment results are available at the USGS Energy Program website, http://energy.usgs.gov/OilGas.aspx.

\section{Liaohe Basin Eastern Uplift Assessment Team}

Richard M. Pollastro (Task Leader), Christopher Potter (Task Chief; cpotter@usgs.gov), Christopher J. Schenk (Task Chief, World Petroleum Resources Project; schenk@usgs.gov), Ronald R. Charpentier, Troy A. Cook, Timothy R. Klett, and Mark A. Kirschbaum. 